\title{
MANAJEMEN DATA PENELITIAN DENGAN DATAVERSE: BEST PRACTICE PUSTAKAWAN MENGGUNAKAN SISTEM REPOSITORI ILMIAH NASIONAL LIPI
}

\author{
Wahid Nashihuddin \\ Pusat Data dan Dokumentasi Ilmiah - LIPI \\ wahed87@gmail.com \\ Seno Yudhanto \\ Pusat Data dan Dokumentasi Ilmiah - LIPI \\ seno.yudhanto@gmail.com \\ Ahmad Saefudin Surapermana \\ Pusat Data dan Dokumentasi Ilmiah - LIPI \\ ahmad_saefudin@hotmail.com \\ Rishadi \\ Pusat Data dan Dokumentasi Ilmiah - LIPI \\ rishadi007@gmail.com
}

\begin{abstract}
This study aims to find out: (1) Dataverse and RIN platforms; (2) research data management with RIN Dataverse; (3) research data usability with RIN Dataverse; and (4) the librarian's challenges in the research data management. The data type of this study is descriptive-qualitative, with document/literature study and simulations through RIN Dataverse as data sources. The study results indicate that: (1) Dataverse is RIN database platform that is open source and can be used to manage effectively, store and share research data; (2) research data management with RIN Dataverse can adopt the research data management of UK Data Service concepts; (3) Research data in RIN Dataverse can be used for science and technology development and quality
\end{abstract}


research data improvement in the future; and (4) Librarians as data managers and depositors in RIN Dataverse need to learn more about the concept of applying research data management based on the characteristics of the institution, and to ready for facing challenges as 'data librarians'. The study recommendations are: (1) the need to increase librarian competence on the research data management; and (2) participation librarians actively in arranging of research data management policies and collaborating in institutional research activities.

Keywords: Research Data Management; Librarian; Research Data Services; Data Curation; Dataverse; National Scientific Repository

\begin{abstract}
Abstrak
Kajian ini bertujuan untuk mengetahui: (1) platform Dataverse dan RIN; (2) pengelolaan data penelitian dengan Dataverse RIN; (3) pemanfaatan data penelitian dengan Dataverse RIN; dan (4) tantangan pustakawan dalam manajemen data penelitian. Jenis data kajian ini bersifat deskriptif-kualitatif dengan sumber data studi dokumen/literatur dan simulasi melalui Dataverse RIN. Hasil kajian ini menunjukkan bahwa: (1) Dataverse merupakan platform database RIN yang bersifat open source dan dapat digunakan untuk efektivitas pengelolaan, penyimpanan, dan berbagi data penelitian; (2) pengelolaan data penelitian dengan Dataverse RIN dapat mengadopsi konsep RDM UK Data Service; (3) Data penelitian di Dataverse RIN dapat dimanfaatkan untuk pengembangan iptek dan peningkatan kualitas data penelitian berikutnya; dan (4) Pustakawan sebagai pengelola data dan depositor di Dataverse RIN perlu belajar lebih banyak tentang konsep penerapan pengelolaan data penelitian berdasarkan karakteristik lembaga dan harus siap menghadapi tantangan sebagai 'pustakawan data'. Rekomendasi kajian ini yaitu: (1) perlunya peningkatan kompetensi pustakawan sebagai pengelolaan data penelitian; dan (2) keaktifan pustakawan dalam penyusunan kebijakan
\end{abstract}


pengelolaan data penelitian dan berkolaborasi dalam kegiatan penelitian lembaga.

Kata kunci: Pengelolaan Data Penelitian; Pustakawan; Layanan Data Penelitian; Kurasi Data; Dataverse; Repositori ilmiah Nasional.

\section{A. Pendahuluan}

Instansi perpustakaan, lembaga penelitian dan pengembangan (litbang), dan lembaga pendidikan tinggi (universitas) pada era digital dan big data seperti sekarang ini telah mulai ramai membicarakan tentang bagaimana mengelola data-data dan karya ilmiah ke dalam suatu database atau portal terintegrasi. Hal tersebut dilakukan agar seluruah data dan karya ilmiah mereka dapat diakses, di-download, dan dibaca dengan mudah serta dapat digunakan kembali oleh peneliti dan masyarakat. Bagi mereka, data dan karya ilmiah telah menjadi aset intelektual yang harus dijaga dan dirawat dengan baik serta dapat diakses dalam jangka waktu yang panjang. Sebagai aset intelektual maka data dan karya ilmiah ini harus dapat dikutip, disitasi, dan digunakan kembali agar dapat berdampak pada peningkatan kualitas penelitian.

Keseriusan dalam pengelolaan data dan karya ilmiah ini harus didukung oleh komitmen yang besar dari lembaga dan sivitas akademika agar dalam pemanfaatannya dapat efektif dan efisien serta berdampak pada peningkatan keilmuan lembaga dan penelitinya. Beberapa komitmen lembaga tersebut dapat diwujudkan dengan membangun database repositori data ilmiah dan melibatkan pustakawan dalam proses manajemen data penelitian (research data management/RDM). MacMillan (2014) mengatakan pustakawan dapat memberikan dukungan penelitian dalam bentuk repositori data ilmiah dan menginformasikan solusi atas permasalahan manajemen data. Terkait hal tersebut, pustakawan perlu mengembangkan keterampilan untuk mendukung pekerjaannya, khususnya ia harus memiliki kompetensi teknologi informasi untuk mengelola data penelitian. 
Dengan kompetensi tersebut pustakawan akan mampu membantu memenuhi kebutuhan informasi dan data bagi para peneliti. Tantangan pustakawan ke depan adalah mengintegrasikan literasi data ke dalam sesi pengajaran dan menyiapkan generasi ilmuan berikutnya dengan menggabungkan pemanfaatan data dan manajemen data dalam alur kerja penelitian mereka.

Farida (2018) mengatakan bahwa dalam era big data, perpustakaan sebagai salah satu penyedia informasi tentunya memiliki sumber data yang terus bertambah dan perlu penanganan khusus dalam manajemen data, apalagi tren penelitian saat ini mengacu pada penelitian berbasis data. Hal senada juga dikatakan Wittenberg, Sackmann, \& Jaffe (2018) bahwa pustakawan berperan sebagai penghubung (liaison) dan domain-sentric dalam menghubungkan peneliti dengan sumber-sumber informasi penting. Selain itu, pustakawan juga berperan sebagai konsultan dalam penentuan topik-topik penelitian yang sedang populer. Aktivitas tersebut merupakan bagian dari RDM. Contohnya pada kegiatan Tim Manajemen Data Penelitian di University of California, Berkeley yang telah menerapkan program dasar pelatihan RDM bagi pustakawan untuk meningkatkan ketrampilan sebagai penghubung kegiatan penelitian dan mendukung supplay data penelitian untuk komunitas penelitiannya. Pustakawan sebagai pengelola perpustakaan juga dituntut memiliki kemampuan dan keterampilan bidang teknologi informasi untuk mengelola data tersebut. Sebagai pengelola data penelitian, pustakawan tidak hanya berperan sebagai penelusur informasi dan penyedia data penelitian, tetapi sebagai aktor utama dalam penelitian yang diwujudkan dalam karya tulis ilmiah serta pengelola data penelitian agar dapat digunakan kembali oleh peneliti lainnya (Carlson \& Kneale, 2011).

Komitmen pengembangan database repositori data ilmiah dan pelibatan pustakawan dalam kegiatan pengelolaan data penelitian ini diimplementasikan oleh Pusat Data dan Dokumentasi Ilmiah - Lembaga Ilmu Pengetahuan Indonesia (PDDI LIPI) dalam 
bentuk database Repositori Ilmiah Nasional (RIN). Database RIN dibangun dengan platform Dataverse (https://dataverse.org/), yaitu sebuah aplikasi web open source untuk berbagi, melestarikan, mengutip, mengeksplorasi, dan menganalisis data penelitian. Berdasarkan uraian di atas, kajian ini membahas empat hal yaitu: (1) sekilas tentang Dataverse dan RIN; (2) pengelolaan data penelitian dengan Dataverse RIN?; (3) pemanfaatan data penelitian dengan Dataverse RIN; dan (4) tantangan pustakawan dalam manajemen data penelitian.

Mengacu pada empat bahan bahasan tersebut, data kajian ini bersifat deskriptif - kualitatif. Data kajian bersumber dari studi dokumen/literatur dan simulasi melalui Dataverse RIN. Hasil simulasi penulis (pustakawan) merupakan best practice (pengetahuan, keterampilan, dan pengalaman) dalam pengelolaan dan pemanfaatan data penelitian melalui Dataverse RIN (Gambar 1).

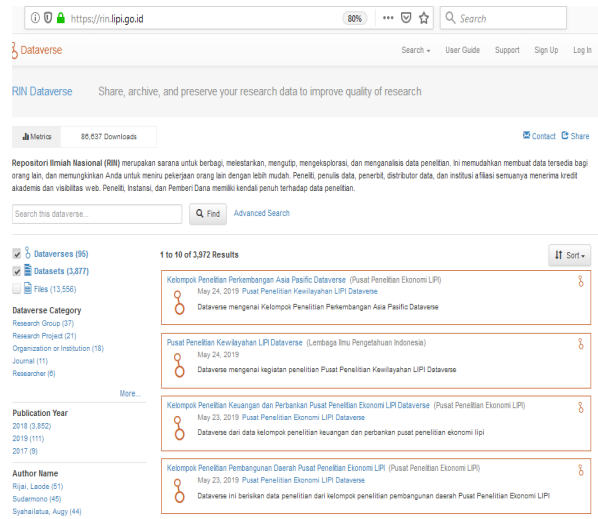

Gambar 1. Database RIN

Sumber: https://rin.lipi.go.id/

Hasil studi dokumen/literatur dan simulasi ini menajdi dasar bahan pembahasan dan kesimpulan kajian ini.

\section{B. Pembahasan}

\section{Sekilas Dataverse dan RIN}

Dataverse adalah perangkat lunak berbasis open source yang memungkinkan hosting ke repositori data penelitian. Dataverse 
menyediakan fitur layanan infrastruktur dan pelestarian arsip, dan memungkinkan para peneliti untuk berbagi, mengendalikan, dan mendapatkan pengakuan untuk data mereka melalui antarmuka browser web yang mudah diakses (https://www.iq.harvard.edu/ product-development). Dataverse dikembangkan oleh The Institute for Quantitative Social Science (IQSS), bersama dengan kolaborator dan kontributor di seluruh dunia. Dataverse dibangun melalui proyek Virtual Data Center (VDC) yang dimulai sejak 1999-2006 kolaborasi antara Pusat Data Harvard-MIT (sekarang bagian dari IQSS) dan Perpustakaan Universitas Harvard.

Fitur Dataverse mencakup layanan untuk: (1) peneliti, mengontrol penuh terhadap aksesibilitas data penelitian, ketersediaan web, kredit akademik, dan peningkatan jumlah sitasi; (2) jurnal, pengelola jurnal dapat mengajukan, meninjau, dan mempublikasikan data terkait dengan artikel yang diterbitkan di jurnal (Open Journal System); (3) institusi, institusi/lembaga dapat menetapkan solusi dan kebijakan pengelolaan data penelitian dalam komunitasnya-mencakup norma-norma untuk berbagi, melestarikan, mengutip, menjelajahi, dan menganalisis data penelitian; (4) pengembang, pengembang web dapat membangun komunitas pengguna dengan memperhatikan norma-norma untuk berbagi, melestarikan, mengutip, menjelajahi, dan menganalisis data penelitian, serta menyumbang ekstensi kode, dokumentasi, pengujian, dan/atau standar.

Di dunia diketahui ada 36 institusi/lembaga yang menggunakan Dataverse untuk mengelola data penelitian, dan daftar lembaganya lihat pada Tabel 1.

Tabel 1. Daftar Institusi/Lembaga Pengguna Dataverse di Dunia

\begin{tabular}{|c|c|c|c|c|}
\hline No & Nama Portal & \multicolumn{1}{|c|}{ Alamat URL } & $\begin{array}{c}\text { Institusi/ } \\
\text { Lembaga }\end{array}$ & Negara \\
\hline 1 & $\begin{array}{l}\text { B o t s w a n a } \\
\text { Harvard Data }\end{array}$ & $\begin{array}{l}\text { https://dataverse. } \\
\text { bhp.org.bw }\end{array}$ & $\begin{array}{l}\text { Botswana Harvard } \\
\text { AIDS Institute } \\
\text { Partnership }\end{array}$ & Bostwana \\
\hline
\end{tabular}




\begin{tabular}{|c|c|c|c|c|}
\hline 2 & $\begin{array}{l}\text { Repositório de } \\
\text { Dados de Pesquisa } \\
\text { da UFABC } \\
\end{array}$ & $\begin{array}{l}\text { http://dataverse. } \\
\text { ufabc.edu.br/ }\end{array}$ & $\begin{array}{l}\text { Universidade } \\
\text { Federal do ABC }\end{array}$ & Brazilia \\
\hline 3 & IBICT & $\begin{array}{l}\mathrm{h} \quad \mathrm{t} \quad \mathrm{t} \quad \mathrm{p} \quad \mathrm{s}: / \mathrm{l} \\
\text { repositoriopesquisas. } \\
\text { ibict.br/ }\end{array}$ & Cariniana Brazilia & Brazilia \\
\hline 4 & $\begin{array}{l}\text { UWI (The } \\
\text { University of the } \\
\text { West Indies) }\end{array}$ & $\begin{array}{l}\text { https://dataverse.sta. } \\
\text { uwi.edu/ }\end{array}$ & $\begin{array}{l}\text { The University of } \\
\text { the West Indies } \\
\text { Research Datasets } \\
\text { Repository }\end{array}$ & Cuba \\
\hline 5 & CIMMYT & $\begin{array}{l}\text { https://data.cimmyt. } \\
\text { org/ }\end{array}$ & $\begin{array}{l}\text { CIMMYT } \\
\text { Research Data } \\
\text { \& Software } \\
\text { Repository } \\
\text { Network } \\
\end{array}$ & Mexico \\
\hline 6 & $\begin{array}{l}\text { UNB Libraries } \\
\text { Dataverse }\end{array}$ & $\begin{array}{l}\text { https://dataverse.lib. } \\
\text { unb.ca/ }\end{array}$ & $\begin{array}{l}\text { the University of } \\
\text { New Brunswick }\end{array}$ & Canada \\
\hline 7 & $\begin{array}{l}\text { D a l h o u s i e } \\
\text { Un i v e r s it y } \\
\text { Dataverse }\end{array}$ & $\begin{array}{l}\text { https://dataverse. } \\
\text { library.dal.ca/ }\end{array}$ & $\begin{array}{l}\text { The Dalhousie } \\
\text { University }\end{array}$ & Canada \\
\hline 8 & $\begin{array}{l}\text { U n i v e r s i t y } \\
\text { of Manitoba } \\
\text { Dataverse }\end{array}$ & $\begin{array}{l}\text { https://dataverse.lib. } \\
\text { umanitoba.ca/ }\end{array}$ & $\begin{array}{l}\text { University of } \\
\text { Manitoba }\end{array}$ & Canada \\
\hline 9 & $\begin{array}{l}\text { Abacus Dataverse } \\
\text { Network }\end{array}$ & $\begin{array}{l}\text { http://dvn.library. } \\
\text { ubc.ca/dvn/ }\end{array}$ & $\begin{array}{l}\text { The British } \\
\text { Columbia } \\
\text { Research } \\
\text { Libraries' Data } \\
\text { Services, }\end{array}$ & Canada \\
\hline 10 & UAL Dataverse & $\begin{array}{l}\text { https://dataverse. } \\
\text { library.ualberta.ca/ }\end{array}$ & $\begin{array}{l}\text { the University of } \\
\text { Alberta Libraries/ } \\
\text { University of } \\
\text { Alberta } \\
\end{array}$ & Canada \\
\hline 11 & Scholars Portal & $\begin{array}{l}\text { https://dataverse. } \\
\text { scholarsportal.info/ }\end{array}$ & $\begin{array}{l}\text { Ontario } \\
\text { universities }\end{array}$ & Canada \\
\hline 12 & $\begin{array}{ll}\text { Texas } & \text { Data } \\
\text { R e p o s i t o r y } \\
\text { Dataverse }\end{array}$ & $\begin{array}{l}\text { https://dataverse.tdl. } \\
\text { org/ }\end{array}$ & $\begin{array}{l}\text { Texas Digital } \\
\text { Library (TDL) }\end{array}$ & $\begin{array}{l}\text { United } \\
\text { States }\end{array}$ \\
\hline 13 & UNC Dataverse & $\begin{array}{l}\text { https://dataverse. } \\
\text { unc.edu/ }\end{array}$ & $\begin{array}{l}\text { the Odum } \\
\text { Institute for } \\
\text { Research in Social } \\
\text { Science }\end{array}$ & $\begin{array}{l}\text { United } \\
\text { States }\end{array}$ \\
\hline
\end{tabular}




\begin{tabular}{|c|c|c|c|c|}
\hline 14 & VTTI & $\begin{array}{l}\text { https://dataverse.vtti. } \\
\text { vt.edu/ }\end{array}$ & $\begin{array}{l}\text { the Virginia Tech } \\
\text { Transportation } \\
\text { Institute } \\
\end{array}$ & $\begin{array}{l}\text { United } \\
\text { States }\end{array}$ \\
\hline 15 & Libra Data & $\begin{array}{l}\text { https://dataverse.lib. } \\
\text { virginia.edu/ }\end{array}$ & $\begin{array}{l}\text { the Rector and } \\
\text { Visitors of the } \\
\text { University of } \\
\text { Virginia }\end{array}$ & $\begin{array}{l}\text { United } \\
\text { States }\end{array}$ \\
\hline 16 & \begin{tabular}{|l|} 
Johns Hopkins \\
University
\end{tabular} & $\begin{array}{l}\text { https://archive.data. } \\
\text { jhu.edu }\end{array}$ & \begin{tabular}{|l} 
Johns Hopkins \\
University \\
\end{tabular} & $\begin{array}{l}\text { United } \\
\text { States } \\
\end{array}$ \\
\hline 17 & 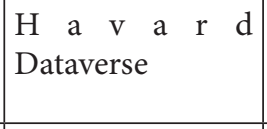 & $\begin{array}{l}\text { https://dataverse. } \\
\text { harvard.edu/ }\end{array}$ & $\begin{array}{l}\text { The President } \\
\text { \& Fellows of } \\
\text { Harvard College } \\
\end{array}$ & $\begin{array}{l}\text { United } \\
\text { States }\end{array}$ \\
\hline 18 & $\begin{array}{l}\text { Maine Dataverse } \\
\text { Network }\end{array}$ & $\begin{array}{l}\text { http://dataverse.acg. } \\
\text { maine.edu/dvn/ }\end{array}$ & $\begin{array}{l}\text { the ACG@ } \\
\text { UMaine }\end{array}$ & $\begin{array}{l}\text { United } \\
\text { States }\end{array}$ \\
\hline 19 & \begin{tabular}{|l|} 
Qualitative Data \\
Repository
\end{tabular} & $\begin{array}{l}\text { https://data.qdr.syr. } \\
\text { edu/ }\end{array}$ & \begin{tabular}{|l|} 
Syracuse \\
University \\
\end{tabular} & $\begin{array}{l}\text { United } \\
\text { States }\end{array}$ \\
\hline 20 & $\begin{array}{l}\text { LIPI Dataverse- } \\
\text { Repositori Ilmiah } \\
\text { Nasional (RIN) } \\
\end{array}$ & https://rin.lipi.go.id/ & $\begin{array}{l}\text { Lembaga Ilmu } \\
\text { Pengetahuan } \\
\text { Indonesia } \\
\end{array}$ & Indonesia \\
\hline 21 & \begin{tabular}{|l|} 
Center for \\
Internation a l \\
Forestry Research \\
(CIFOR)
\end{tabular} & https://data.cifor.org/ & \begin{tabular}{|l} 
Center for \\
International \\
Forestry Research \\
(CIFOR) \\
\end{tabular} & Indonesia \\
\hline 22 & DR-NTU (Data) & $\begin{array}{l}\text { https://researchdata. } \\
\text { ntu.edu.sg/ }\end{array}$ & $\begin{array}{l}\text { Nanyang } \\
\text { Technological } \\
\text { University (NTU) }\end{array}$ & Singapore \\
\hline 23 & $\begin{array}{l}\text { DataSpace@ } \\
\text { HKUST }\end{array}$ & $\begin{array}{l}\text { https://dataspace.ust. } \\
\text { hk/ }\end{array}$ & $\begin{array}{l}\text { HKUST Library, } \\
\text { The Hong Kong } \\
\text { University of } \\
\text { Science and } \\
\text { Technology } \\
\end{array}$ & China \\
\hline 24 & \begin{tabular}{|lr} 
Fudan & University \\
Social & Science \\
Data & Repository \\
\end{tabular} & $\begin{array}{l}\text { https://dvn.fudan. } \\
\text { edu.cn/home/ }\end{array}$ & Fudan University & China \\
\hline 25 & $\begin{array}{|llllll|} & \text { e } & k & i & n & g \\
\text { University } & & \\
\end{array}$ & $\begin{array}{l}\text { http://opendata.pku. } \\
\text { edu.cn/ }\end{array}$ & Peking University & China \\
\hline 26 & 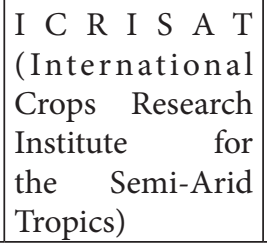 & $\begin{array}{l}\text { http://d at averse. } \\
\text { icrisat.org/ }\end{array}$ & $\begin{array}{l}\text { The International } \\
\text { Crops Research } \\
\text { Institute for the } \\
\text { Semi-Arid Tropics } \\
\text { (ICRISAT) }\end{array}$ & India \\
\hline
\end{tabular}




\begin{tabular}{|c|c|c|c|c|}
\hline 27 & $\begin{array}{l}\text { ADA Dataverse- } \\
\text {-The Australian } \\
\text { Data Archive }\end{array}$ & $\begin{array}{l}\text { https://dataverse.ada. } \\
\text { edu.au/ }\end{array}$ & $\begin{array}{l}\text { Institute for } \\
\text { Quantitative } \\
\text { Social Science }\end{array}$ & Australia \\
\hline 28 & $\begin{array}{l}\text { DataversenO } \\
\text { ( } \mathrm{N} \text { e } \mathrm{t} \text { w o r k s } \\
\text { Norway) }\end{array}$ & https://dataverse.no/ & $\begin{array}{l}\text { UiT The Arctic } \\
\text { University of } \\
\text { Norway }\end{array}$ & Norwaygia \\
\hline 29 & $\begin{array}{l}\mathrm{D} \text { a } \mathrm{t} \text { a } \mathrm{v} \text { e } \mathrm{r} \mathrm{s} \text { e } \\
\mathrm{e} \text {-cienciaDatos }\end{array}$ & $\begin{array}{l}\text { https:// ed atos. } \\
\text { consorciomadrono. } \\
\text { es/ }\end{array}$ & $\begin{array}{l}\text { Consorcio } \\
\text { Madroño }\end{array}$ & Spanyol \\
\hline 30 & $\begin{array}{l}\text { C I R A D : } \\
\text { A gricult ur e } \\
\text { Research and } \\
\text { Development }\end{array}$ & $\begin{array}{l}\text { https://dataverse. } \\
\text { cirad.fr/ }\end{array}$ & $\begin{array}{l}\text { CIRAD: } \\
\text { Agriculture } \\
\text { Research and } \\
\text { Development }\end{array}$ & France \\
\hline 31 & $\begin{array}{l}\text { C a t a lo g u e s } \\
(\text { CDSP })\end{array}$ & $\begin{array}{l}\text { https://catalogues. } \\
\text { cdsp.sciences-po.fr/ }\end{array}$ & $\begin{array}{l}\text { Center for Socio- } \\
\text { Political Data } \\
\text { (Sciences Po and } \\
\text { CNRS) }\end{array}$ & France \\
\hline 32 & $\begin{array}{l}\text { INRA Science \& } \\
\text { Impact }\end{array}$ & https://data.inra.fr/ & INRA & France \\
\hline 33 & 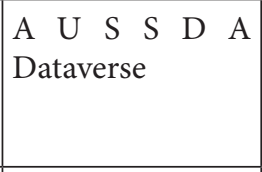 & $\begin{array}{l}\text { https://data.aussda. } \\
\text { at/ }\end{array}$ & $\begin{array}{l}\text { AUSSDA - The } \\
\text { Austrian Social } \\
\text { Science Data } \\
\text { Archive }\end{array}$ & Austria \\
\hline 34 & HeiDATA & $\begin{array}{l}\text { https://heidata.uni- } \\
\text { heidelberg.de/ }\end{array}$ & $\begin{array}{l}\text { Heidelberg } \\
\text { University }\end{array}$ & Germany \\
\hline 35 & IISH Dataverse & $\begin{array}{l}\text { https://datasets. } \\
\text { socialhistory.org/ }\end{array}$ & $\begin{array}{l}\text { The Institute } \\
\text { for Quantitative } \\
\text { Social Science/ } \\
\text { The President } \\
\text { \& Fellows of } \\
\text { Harvard College }\end{array}$ & Netherlands \\
\hline 36 & DataverseNL & https://dataverse.nl/ & $\begin{array}{l}\text { Data Archiving } \\
\text { and networking } \\
\text { Services (DANS)/ } \\
\text { Dutch universities }\end{array}$ & Netherlands \\
\hline
\end{tabular}

Sumber: https://dataverse.org/

Tabel 1 menunjukkan bahwa ada 17 negara yang telah memanfaatan Dataverse untuk pengelolaan data penelitian. Kemudian pada Tabel 2 dan Gambar 2 ditunjukkan bahwa negara yang paling banyak memanfaatkan Dataverse adalah United States (8 lembaga), yaitu Texas Data Repository Dataverse, UNC Dataverse, VTTI, Libra Data, Johns Hopkins University, Havard 
Dataverse, Maine Dataverse Network, dan Qualitative Data Repository. Sementara di Indonesia hanya ada 2 lembaga pengguna Dataverse, yaitu Center for International Forestry Research (CIFOR) dan Lembaga Ilmu Pengetahuan Indonesia (LIPI).

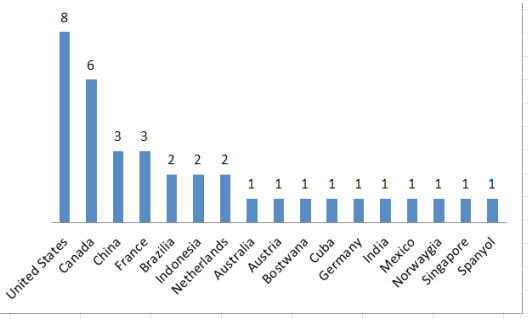

Gambar 2. Jumlah Dataverse di Berbagai Negara

Platform Dataverse ini menjadi dasar pengembangan database RIN di LIPI sejak tahun 2016. RIN merupakan sarana untuk berbagi, melestarikan, mengutip, mengeksplorasi, dan menganalisis data penelitian (https://rin.lipi.go.id/). Platform ini memfasilitasi untuk membuat data secara online yang memungkinkan pemilik data dan pengguna lain dapat mereplikasi pekerjaan penelitian orang lain dengan mudah. Tujuan lembaga membangun database RIN yaitu untuk: (1) meningkatkan kesadaran para peneliti (di Indonesia) untuk berbagi data ilmiah/ penelitian guna peningkatan iptek dan kualitas hasil penelitian; (2) menyediakan sistem interoperabilitas pengelolaan data penelitian terintegrasi secara nasional.

Pengaturan hak akses data penelitian di database RIN diserahkan kepada pemilik data, apakah data akan dibuka (open access) atau ditutup (closed access), sedangkan lembaga (PDDI LIPI) hanya berperan sebagai fasilitator dan depositor nasional untuk integrasi pengelolaan dan pemanfaatan data penelitian di Indonesia. Melalui database RIN, pengguna dapat kolaborasi dengan berbagai pihak pusat penelitian dan meminta untuk segera mempublikasikan aset penelitiannya sehingga masyarakat lebih mudah mendapatkan informasi dan membuat data center (Tempo. Co, 2019). Selain itu, pemilik data akan lebih mudah melakukan 
penyimpanan dan berbagi data, mendapatkan jaminan keteraksesan dan keamanan data dalam suatu sistem online yang terintegrasi.

\section{Pengelolaan Data Penelitian Dengan Dataverse RIN}

Manajemen atau pengelolaan data penelitian merupakan suatu proses untuk mengelola, menemukan, mengakses, dan menggunakan data, informasi dan semua hal yang berkaitan dengan kegiatan penelitian. Tujuan dari RDM ada Manajemen data penelitian bertujuan untuk: (1) memudahkan pemanfaatan kembali data primer penelitian untuk data pendukung pengembangan penelitian; (2) meningkatkan reputasi peneliti atau lembaga yang bersangkutan melalui sitasi dari penggunaan data; (3) menghubungkan antara data primer penelitian dan hasil penelitian (karya ilmiah).

Dalam mengelola data penelitian, pustakawan (sebagai depositor, kurator, dan sebagainya, lihat Tabel 3) perlu memperhatikan siklus hidup data penelitian agar data yang dipreservasi dapat selalu tersedia dan diakses dalam jangka waktu panjang. Siklus hidup data penelitian ini dapat mengacu dan mengadopsi siklus hidup data penelitian UK Data Service (Gambar 3).

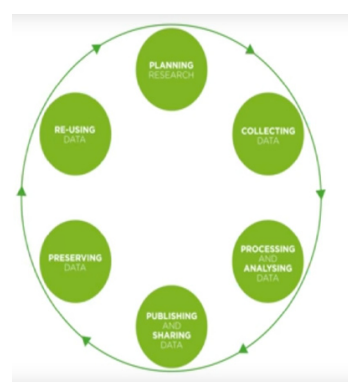

Gambar 3. Siklus hidup data penelitian UK Data Service (Sumber: https://www.ukdataservice.ac.uk/manage-data/lifecycle)

Mengacu pada siklus hidup penelitian UK Data Service, pengelolaan data penelitian di Indonesia melalui Dataverse RIN dapat dilakukan dengan tahapan sebagai berikut (Tabel 2). 
Tabel 2. Tahapan RDM Adopsi Siklus Hidup Data Penelitian UK Data Service

\begin{tabular}{|c|c|c|c|}
\hline No & $\begin{array}{c}\text { Siklus Hidup Data } \\
\text { Penelitian } \\
\text { (UK Data Service) }\end{array}$ & $\begin{array}{c}\text { Pengelolaan Data } \\
\text { Penelitian Melalui } \\
\text { Dataverse RIN }\end{array}$ & $\begin{array}{c}\text { Program RDM } \\
\text { melalui } \\
\text { Dataverse RIN }\end{array}$ \\
\hline 1 & $\begin{array}{l}\text { Perencanaan penelitian } \\
\text { (Planning research) } \\
\text { - Rencana penelitian } \\
\text { - Manajemen } \\
\text { perencanaan data } \\
\text { - Fokus perencanaan } \\
\text { berbagi } \\
\text { - Rencana } \\
\text { pengumpulan data, } \\
\text { pengolahan protokol } \\
\text { - Eksplorasi } \\
\text { ketersediaan sumber } \\
\text { data }\end{array}$ & $\begin{array}{l}\text { - Membuat kebijakan } \\
\text { deposit data penelitian } \\
\text { di Dataverse RIN } \\
\text { - Menyusun proposal } \\
\text { berdasarkan data dan } \\
\text { kebutuhan kegiatan } \\
\text { penelitian } \\
\text { - Mendepositkan } \\
\text { proposal dan data } \\
\text { pendukung penelitian } \\
\text { ke Dataverse RIN }\end{array}$ & $\begin{array}{l}\text { - Melakukan } \\
\text { sosialisasi dan } \\
\text { bimtek pengelolaan } \\
\text { dan pemanfaatan } \\
\text { data penelitian } \\
\text { melalui RIN } \\
\text { - Inisiasi kerjasama } \\
\text { dan MoU } \\
\text { pengelolaan data } \\
\text { data penelitian } \\
\text { melalui RIN } \\
\text { - Pengusulan jabatan } \\
\text { kurator data }\end{array}$ \\
\hline 2 & $\begin{array}{l}\text { Pengumpulan data } \\
\text { (Collecting Data) } \\
\text { - Pengumpulan data } \\
\text { - Meng-capture data } \\
\text { dengan metadata } \\
\text { - Memperoleh } \\
\text { ketersediaan bagian } \\
\text { data }\end{array}$ & $\begin{array}{l}\text { - Menentukan teknik } \\
\text { pengumpulan data } \\
\text { - Menklasifikasi dan } \\
\text { mengidentifikasi jenis } \\
\text { data } \\
\text { - Mendepositkan data } \\
\text { yang terkumpul ke } \\
\text { Dataverse RIN }\end{array}$ & $\begin{array}{l}\text { penelitian ke LIPI } \\
\text { - Pengembangan } \\
\text { sistem dan fitur } \\
\text { Dataverse RIN } \\
\text { secara bertahap } \\
\text { - Membuat laporan } \\
\text { pemanfaatan data } \\
\text { dalam kurun waktu } \\
\text { tertentu }\end{array}$ \\
\hline
\end{tabular}




\begin{tabular}{|c|c|c|}
\hline 3 & $\begin{array}{l}\text { Proses dan analisis } \\
\text { (Processing and } \\
\text { Analizing) } \\
\text { - Memasukkan, } \\
\text { mendigitalkan, } \\
\text { menuliskan, dan } \\
\text { menerjemahkan data } \\
\text { - Mengecek, } \\
\text { memvalidasi, } \\
\text { membersihkan, } \\
\text { menghilangkan } \\
\text { identitas } \\
\text { - Mengirim data } \\
\text { - Mendeskripsikan dan } \\
\text { mendokumentasikan } \\
\text { data } \\
\text { - Mengelola dan } \\
\text { menyimpan data } \\
\text { - Menganalisis dan } \\
\text { menginterpretasikan } \\
\text { data } \\
\text { - Memproduksi hasil } \\
\text { penelitian } \\
\text { - Mensitasi sumber data }\end{array}$ & $\begin{array}{l}\text { - Menetapkan } \\
\text { perangkat/ aplikasi } \\
\text { pengolah data } \\
\text { - Menyiapkan data } \\
\text { terolah untuk deposit } \\
\text { data ke Dataverse RIN }\end{array}$ \\
\hline
\end{tabular}




\begin{tabular}{|c|c|c|}
\hline 4 & $\begin{array}{l}\text { Publikasi dan berbagi } \\
\text { data (Publishing and } \\
\text { sharing data) } \\
\text { - Memastikan copyright } \\
\text { - Membuat } \\
\text { dokumentasi } \\
\text { pengguna } \\
\text { - Membuat deskripsi } \\
\text { metadata } \\
\text { - Menyeleksi kesesuaian } \\
\text { data } \\
\text { - Mempublikasikan/ } \\
\text { membagikan data } \\
\text { - Mempromosikan data }\end{array}$ & \begin{tabular}{|l} 
- Mengatur hak akses \\
deposit data di \\
Dataverse RIN \\
- Menetapkan \\
pengguna data (publik \\
atau grup/komunitas)
\end{tabular} \\
\hline 5 & \begin{tabular}{|l} 
Preservasi data \\
(Preserving data) \\
- Migrasi data ke format/ \\
media terbaik \\
- Menyimpan dan mem- \\
backup data \\
- Membuat dokumentasi \\
preservasi \\
- Menjaga dan \\
mengkurasi data \\
\end{tabular} & $\begin{array}{l}\text { - Melakukan back } \\
\text { up data penelitian } \\
\text { ke database selain } \\
\text { Dataverse RIN } \\
\text { - Migrasi data } \\
\text { dan membuat } \\
\text { dokumentasi } \\
\text { preservasi data }\end{array}$ \\
\hline 6 & \begin{tabular}{|l} 
Penggunaan kembali \\
data (Re Using data) \\
- Menghubungkan \\
dengan sistem analisis \\
- Melakukan penelitian \\
pengembangan \\
- Menghubungkan \\
review penelitian \\
- Meneliti pendanaan \\
- Menggunakan data \\
untuk pengajaran dan \\
pembejaran
\end{tabular} & $\begin{array}{l}\text { - Menginformasikan } \\
\text { pemanfaatan } \\
\text { data penelitian di } \\
\text { Dataverse RIN ke } \\
\text { publik, baik melalui } \\
\text { pertemanan, research } \\
\text { group, media sosial, } \\
\text { web/database lain }\end{array}$ \\
\hline
\end{tabular}


Berikut ini ada beberapa hal yang perlu diperhatikan pustakawan atau pengelola data ketika mengelola data penelitian melalui Dataverse RIN:

1. Pengelolaan data penelitian ini dapat dilakukan oleh individu (peneliti/pemilik data), grup/komunitas, ataupun institusi/lembaga.

2. Pengelola data dapat mengoperasionalkan Dataverse RIN mulai dari pembuatan akun pengguna, manajemen dataverse dan dataset, pengaturan peran, pendeskripsian metadata, pengaturan akses data, validasi/kurasi data, publikasi, berbagi data, hingga penggunaan kembali data penelitian.

3. Penamaan Dataverse dan/atau Dataset dapat ditetapkan berdasarkan kebijakan pemilik data, apakah berdasarkan nama departemen, jurnal, laboratorium, organisasi atau institusi, peneliti, grup peneliti, proyek penelitian, kursus pembelajaran, atau kategori lainnya.

Pada saat mengelola konten data penelitian, depositor data harus mengetahui hierarki manajemen Dataverse-Dataset_File. Dataverse adalah ruang penyimpanan Dataverse adalah tempat kumpulan dari beberapa Dataset dan juga dapat berisi kumpulan Dataverse (data penelitian, kode, dokumentasi, dan metadata) dan data lainnya yang dapat diatur sesuai kebutuhan peneliti, departemen, jurnal, dan organisasi (Gambar4). Agar dataset dapat terpublikasi, pengguna harus mempublikasikan Dataverse terlebih dahulu sebelum dataset dalam dataverse itu dapat dipublikasikan. Dataset adalah wadah untuk menyimpan dan mengelola data, dokumentasi, kode, dan deskripsi metadata yang menggambarkan Dataset tersebut (Gambar 5). Dataset terdiri dari tiga level metadata, antara lain:

1. Citation Metadata, metadata apapun yang diperlukan untuk menghasilkan kutipan data dan metadata umum lainnya dapat diterapkan ke Dataset apapun. 
2. Domain Specific Metadata, dukungan khusus ini digunakan untuk Dataset Social Science, Life Science, Geospatial, and Astronomy.

3. File-level Metadata, bervariasi tergantung pada jenis file data.

Sedangkan file adalah objek digital yang disimpan dalam format tertentu yang terbaca oleh sistem komputer. Format file data yang dapat disimpan di Dataverse mencakup: (1) Image: JPEG, JPG2000, PNG, TIFF, GIF; (2) Text: plain text (TXT), HTML, XML, PDF/A, PDF, DOC, RTF; (3) Audio: AIFF, WAVE; (4) Containers: TAR, GZIP, ZIP, RAR; (5) Databases: prefer XML or CSV to native binary formats (Dataverse, 2019).

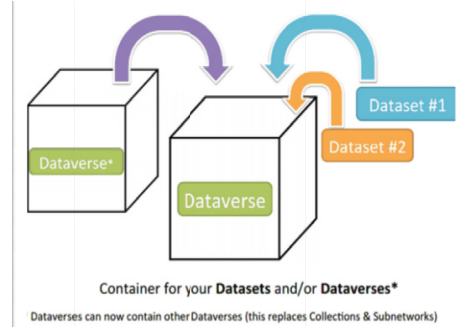

Gambar 4. Skema diagram manajemen dataverse dan dataset

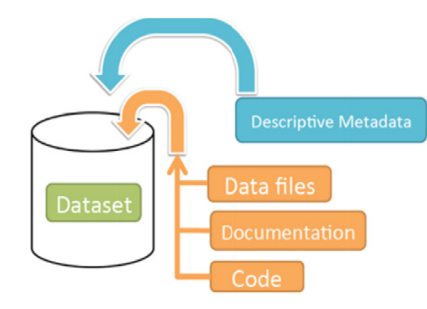

Container for your data, documentation, and code.

Gambar 5. Skema diagram manajemen dataset dan file

\section{Pemanfaatan Data Penelitian dengan Dataverse RIN}

Dalam pemanfaatan data penelitian, depositor data harus memahami beberapa peran dan kompetensi berikut ini (Tabel 3).

Tabel 3. Daftar Peran \& Kompetensi Pengelola Data Penelitian di Dataverse

\begin{tabular}{|c|c|l|l|}
\hline No & Peran & \multicolumn{1}{|c|}{ Deskripsi } & \multicolumn{1}{c|}{ Kompetensi } \\
\hline 1 & Admin & $\begin{array}{l}\text { Peran yang memiliki } \\
\text { seluruh izin akses } \\
\text { untuk Dataverse, } \\
\text { Dataset, dan file. }\end{array}$ & $\begin{array}{l}\text { Memahami \& mengetahui sistem kerja } \\
\text { aplikasi Dataverse } \\
\text { Memahami level dan mampu membuat } \\
\text { peran pengguna berdasarkan tugas } \\
\text { dalam pengelolaan data }\end{array}$ \\
\hline \multirow{2}{*}{ Curator } & $\begin{array}{l}\text { Peran yang dapat } \\
\text { meng u b h / e d it t } \\
\text { ketentuan dan } \\
\text { lisensi Dataset dan } \\
\text { menerbitkan Dataset. }\end{array}$ & $\begin{array}{l}\text { Memahami dan mampu melakukan } \\
\text { proses kurasi data penelitian mulai dari } \\
\text { akuisisi data, manajemen dataverse/ } \\
\text { dataset/file, validasi data, publish } \\
\text { data, dan pemanfaatan kembali data }\end{array}$ \\
\hline
\end{tabular}




\begin{tabular}{|c|c|c|c|}
\hline 3 & Contributor & $\begin{array}{l}\text { Peran yang dapat } \\
\text { me n g u b h / e d it } \\
\text { ketentuan dan lisensi } \\
\text { Dataset, serta submit } \\
\text { untuk di-review. } \\
\end{array}$ & $\begin{array}{l}\text { Mampu melakukan submit data dan } \\
\text { editing data dalam dataset }\end{array}$ \\
\hline 4 & $\begin{array}{l}\text { Dataset } \\
\text { Creator }\end{array}$ & $\begin{array}{l}\text { Peran yang dapat } \\
\text { m e } \mathrm{n} \text { a } \mathrm{m} \text { b h ka } \mathrm{n} \\
\text { Dataset ke dalam } \\
\text { Dataverse. }\end{array}$ & $\begin{array}{l}\text { Mampu membuat dataset dan } \\
\text { mengelola file data dalam dataset }\end{array}$ \\
\hline 5 & $\begin{array}{l}\text { Dataverse } \\
+ \text { Dataset } \\
\text { Creator }\end{array}$ & $\begin{array}{l}\text { Peran yang dapat } \\
\text { m e n a m ba h ka n } \\
\text { Dataverse ke dalam } \\
\text { Dataverse r (sub- } \\
\text { Dataverse) r dan } \\
\text { m e n a m b h ka n } \\
\text { Dataset ke dalam } \\
\text { Dataverse. } \\
\end{array}$ & $\begin{array}{l}\text { Mampu membuat dan mengelola } \\
\text { Dataverse dan Dataset dalam suatu/ } \\
\text { berbagai research project } \\
\text { Mampu mengedit metadata } \\
\text { Dataverse, Dataset, dan File dalam } \\
\text { suatu/berbagai research project }\end{array}$ \\
\hline 6 & $\begin{array}{l}\text { Dataverse } \\
\text { Creator }\end{array}$ & $\begin{array}{l}\text { Peran yang dapat } \\
\text { m e n a m b a k a n } \\
\text { Dataverse ke dalam } \\
\text { Dataverse } \\
\text { Dataverse). } \\
\end{array}$ & $\begin{array}{l}\text { Mampu membuat dataverse utama } \\
\text { dan sub-dataverse secara sistematis }\end{array}$ \\
\hline 7 & $\begin{array}{c}\text { File } \\
\text { Downloader }\end{array}$ & $\begin{array}{l}\text { Peran yang dapat } \\
\text { mengunduh file yang } \\
\text { sudah diterbitkan. }\end{array}$ & 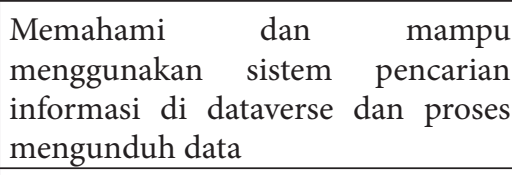 \\
\hline 8 & Member & $\begin{array}{l}\text { Peran yang dapat } \\
\text { melihat Dataverse } \\
\text { dan Dataset yang } \\
\text { belum diterbitkan. }\end{array}$ & $\begin{array}{l}\text { Memahami cara registrasi dan } \\
\text { mampu menggunakan sistem } \\
\text { pencarian informasi di dataverse }\end{array}$ \\
\hline
\end{tabular}

Sumber: Roles in the Texas Data Repository (McEniry \& Mumma, 2018)

Berdasarkan peran pengguna di atas, depositor dan pengguna umum dapat memanfaatkan kembali data penelitian melalui Dataverse RIN dengan cara: (1) menelusur dan mendownload data penelitian melalui Dataverse RIN sesuai kebutuhan. Apabila data dibatasi aksesnya (dengan alasan tertentu), pengguna dapat menghubungi pemilik data melalui menu request access; (2) data yang telah di-donwload, dimanfaatkan untuk pengembangan penelitian sejenis (satu bidang keilmuan) atau untuk meningkatkan kolaborasi penelitian, baik antar-individu peneliti maupun antarinstansi/lembaga. Platform Dataverse juga memungkinkan peneliti 
melakukan kolaborasi dalam memanfaatkan data penelitian baik untuk internal tim penelitian maupun eksternal tim penelitian (Yoganingrum, et al. 2015).

\section{Tantangan Pustakawan dalam Manajemen Data Penelitian}

Lembaga atau institusi yang telah menetapkan kebijakan pengelolaan data penelitian seperti di LIPI dan beberapa lembaga litbang di Indonesia, telah menempatkan perpustakaan sebagai sumber referensi penelitian dan pustakawan sebagai kolaborator dan pengelolah data penelitian. Kebijakan tersebut tentunya berdampak pada pergeseran (shifting) peran pustakawan di lembaga tersebut. Sebagaimana yang terjadi pada pustakawan di LIPI, yakni sejak ujicoba pengembangan Database RIN pada tahun 2015 dan diterbitkannya dokumen kebijakan pengelolaan data penelitian di lingkungan LIPI, yaitu: (1) Naskah Akademik Rancangan Kebijakan Implementasi Repositori Ilmiah Nasional; (2) Peraturan Kepala Lembaga Ilmu Pengetahuan Indonesia Republik Indonesia Nomor 12 Tahun 2016 tentang Repositori dan Depositori Lembaga Ilmu Pengetahuan Indonesia; dan (3) Peraturan Kepala LIPI Nomor 1 Tahun 2019 tentang Organisasi dan Tata Kerja Lembaga Ilmu Pengetahuan Indonesia, peran pustakawan di LIPI bergeser dari pustakawan pengelola koleksi perpustakaan menjadi pustakawan pengelola data ilmiah. Selain itu, tugas dan fungsi PDDI juga bergeser dari pusat dokumentasi dan informasi ilmiah menjadi pusat repositori dan depositori (data) ilmiah dan non-ilmiah. Mengacu tugas dan fungsi lembaga, Pustakawan PDDI dituntut mampu melakukan penyusunan kebijakan teknis, rencana, dan program pengelolaan data, informasi, dan dokumentasi ilmiah dan non-ilmiah.

Sebagai pustakawan pengelola data penelitian lembaga, ia memiliki tantangan dalam pelaksanaan tugas dan pekerjaannya. Ada beberapa tantangan pustakawan dalam pengelolaan data penelitian lembaga, yakni sebagai berikut. 


\section{Mampu memahami konsep dan proses kurasi data penelitian di Dataverse RIN}

Kurasi data telah muncul sebagai area tanggung jawab baru bagi peneliti, pustakawan, dan profesional informasi di lingkungan perpustakaan digital (Tammaro, et al., 2017). Dalam beberapa tahun terakhir, pengembangan di bidang kurasi digital dan kurasi data terjadi secara cepat serta di tahun 2007 peran digital data kurasi untuk perpustakaan dan pustakawan menjadi topik baru di penelitian, percakapan, perkembangan kebijakan, pendidikan dan perdebatan (Kusumaningrum, Riyanto, \& Triasih, 2018). Adapun proses kurasi data penelitian di Dataverse RIN, yaitu:

1) Menilai dan memilih dataset yang sudah di-input ke Dataverse RIN, apakah sudah sesuai kriteria sebagai data penelitian atau tidak. Jika tidak sesuai kriteria, kurator menginformasikannya ke pemilik data. Kriteria data penelitian menurut DMPTool (2019) yaitu data penelitian yang bersumber dari kegiatan: (a) observasi (pembacaan sensor, telemetri, hasil survei, gambar); (b) eksperimental (sekuens gen, kromatogram, pembacaan medan magnet); (c) simulasi (model iklim, model ekonomi); dan (d) asli/kompilasi (penambangan teks dan data, database terkompilasi, model 3D).

2) Memeriksa kelengkapan metadata, apakah sudah lengkap atau sesuai pada setiap Dataset. Jika tidak lengkap, kurator melengkapi metadata deskriptif data, sedangkan substabsi datanya dikembalikan kepada pemilik data.

3) Mengecek dan meninjau konten file data, apakah data dapat dibaca dengan perangkat aplikasi komputer atau ditutup aksesnya. Jika file data tidak dapat dibuka/ dibaca, kurator menginformasikannya ke pemilik data tentang tata cara membaca file data tersebut dalam 
sebuah catatan file dokumensi (contoh: readme text) yang di-upload ulang pada Dataset.

4) Mengecek struktur data tabular (Ms.Excel atau .csv), apakah memiliki identitas header pada setiap data tabular dalam satu Dataset. Jika tidak ada, pemilik data melengkapi identitas header-termasuk menjelaskan mengenai cell yang kosong dan satuan pengukuran pada setiap data dalam satu data tabular.

5) Mengubah format file ke format umum yang terbaca oleh aplikasi umum dan terkini, misalnya data tabular apapun dapat dibuka menggunakan aplikasi spread sheet umum, seperti Ms.Excel atau Libre Office.

6) Mengevaluasi hasil kurasi data, apakah Dataset tersebut mudah diakses dan ditemukan dengan konsep FAIRness (Fineable, Accesible, Interoperable, Reuseable) atau sulit ditemukan. Jika sulit ditemukan, kurator memahami kembali isi Dataset yang sudah di-upload dan konfirmasi ulang ke pemilik data (untuk perbaikan isi metadata).

7) Mendokumentasikan semua kegiatan tahapan kurasi data untuk bahan perbaikan kualitas data di Dataverse RIN.

\section{Mampu mendeskripsikan data penelitian berdasarkan standar metadata di Dataverse}

Skema cantuman/ruas metadata Dataverse RIN menggunakan metadata deskriptif berdasarkan Data Documentation Initiative (DDI), yaitu standar internasional untuk menggambarkan data yang dihasilkan oleh survei dan metode pengamatan lainnya dalam bidang ilmu sosial, perilaku, ekonomi, dan kesehatan (https://www.ddialliance. org/). Metadata deskripstif data di Dataverse RIN ditetapkan berdasarkan jenis data dan bidang keilmuan (Tabel 4).

Tabel 4. Skema Cantuman/Ruas Metadata di Dataverse* 
Manajemen Data Penelitian dengan Dataverse

\begin{tabular}{|c|c|c|c|c|c|}
\hline \multicolumn{4}{|c|}{ Kolom Cantuman/ Ruas Metadata Dataverse } & \multirow[b]{2}{*}{$\begin{array}{l}\text { ILMU } \\
\text { ASTRONOMI } \\
\& \\
\text { ASTROFISIKA }\end{array}$} & \multirow[b]{2}{*}{$\begin{array}{l}\text { ILMU } \\
\text { HAYATI }\end{array}$} \\
\hline SITASI & JURNAL & $\begin{array}{l}\text { DATA } \\
\text { GEOSPASIAL }\end{array}$ & $\begin{array}{l}\text { ILMU } \\
\text { SOSIAL \& } \\
\text { HUMANIORA }\end{array}$ & & \\
\hline Title & Journal & \begin{tabular}{|l|} 
Geographic \\
Coverage
\end{tabular} & $\begin{array}{l}\text { Unit of } \\
\text { Analysis }\end{array}$ & Type & Design Type \\
\hline Sub Title & Volume & $\begin{array}{l}\text { Country/ } \\
\text { Nation }\end{array}$ & Universe & Facility & Factor Type \\
\hline $\begin{array}{l}\text { Alternative } \\
\text { Title } \\
\end{array}$ & Issue & \begin{tabular}{|l|} 
State/ \\
Province \\
\end{tabular} & Time Method & Instrument & Organism \\
\hline \begin{tabular}{|l|} 
Alternative \\
URL \\
\end{tabular} & \begin{tabular}{|l|} 
Publication \\
Date
\end{tabular} & City & \begin{tabular}{|l} 
Data \\
Collector
\end{tabular} & Object & $\begin{array}{l}\text { Other } \\
\text { Organism } \\
\end{array}$ \\
\hline Other ID & $\begin{array}{l}\text { Type of } \\
\text { Article }\end{array}$ & Other & $\begin{array}{l}\text { Collector } \\
\text { Training } \\
\end{array}$ & $\begin{array}{l}\text { Spatial } \\
\text { Resolution } \\
\end{array}$ & \begin{tabular}{|l} 
Measurement \\
Type
\end{tabular} \\
\hline Agency & & $\begin{array}{l}\text { Geographic } \\
\text { Unit }\end{array}$ & Frequency & $\begin{array}{l}\text { Spectral } \\
\text { Resolution }\end{array}$ & $\begin{array}{l}\text { Other } \\
\text { Measurement } \\
\text { Type } \\
\end{array}$ \\
\hline Identifier & & \begin{tabular}{|l|} 
Geographic \\
Bounding \\
Box \\
\end{tabular} & $\begin{array}{l}\text { Sampling } \\
\text { Procedure }\end{array}$ & $\begin{array}{l}\text { Time } \\
\text { Resolution }\end{array}$ & $\begin{array}{l}\text { Technology } \\
\text { Type }\end{array}$ \\
\hline Author & & \begin{tabular}{|l} 
West \\
Longitude \\
\end{tabular} & $\begin{array}{l}\text { Target Sample } \\
\text { Size }\end{array}$ & Bandpass & $\begin{array}{l}\text { Technology } \\
\text { Platform }\end{array}$ \\
\hline Name & & $\begin{array}{l}\text { East } \\
\text { Longitude }\end{array}$ & Actual & \begin{tabular}{|l} 
Central \\
Wavelength \\
$(\mathrm{m})$ \\
\end{tabular} & Cell Type \\
\hline Affiliation & & $\begin{array}{l}\text { North } \\
\text { Latitude }\end{array}$ & Formula & $\begin{array}{l}\text { Wavelength } \\
\text { Range } \\
\end{array}$ & \\
\hline $\begin{array}{l}\text { Identifier } \\
\text { Scheme }\end{array}$ & & $\begin{array}{l}\text { South } \\
\text { Latitude }\end{array}$ & \begin{tabular}{|l|} 
Major \\
Deviations \\
for Sample \\
Design \\
\end{tabular} & Minimum (m) & \\
\hline Identifier & & & $\begin{array}{l}\text { Collection } \\
\text { Mode } \\
\end{array}$ & \begin{tabular}{|l|}
$\begin{array}{l}\text { Maksimum } \\
(\mathrm{m})\end{array}$ \\
\end{tabular} & \\
\hline Contact & & & \begin{tabular}{|l} 
Type of \\
Research \\
Instrument \\
\end{tabular} & $\begin{array}{l}\text { Dataset Date } \\
\text { Range }\end{array}$ & \\
\hline Name & & & $\begin{array}{l}\text { Characteristics } \\
\text { of Data } \\
\text { Collection } \\
\text { Situation } \\
\end{array}$ & Start & \\
\hline Affiliation & & & \begin{tabular}{|l} 
Actions to \\
Minimize \\
Losses \\
\end{tabular} & End & \\
\hline
\end{tabular}


Wahid Nashihuddin, dkk

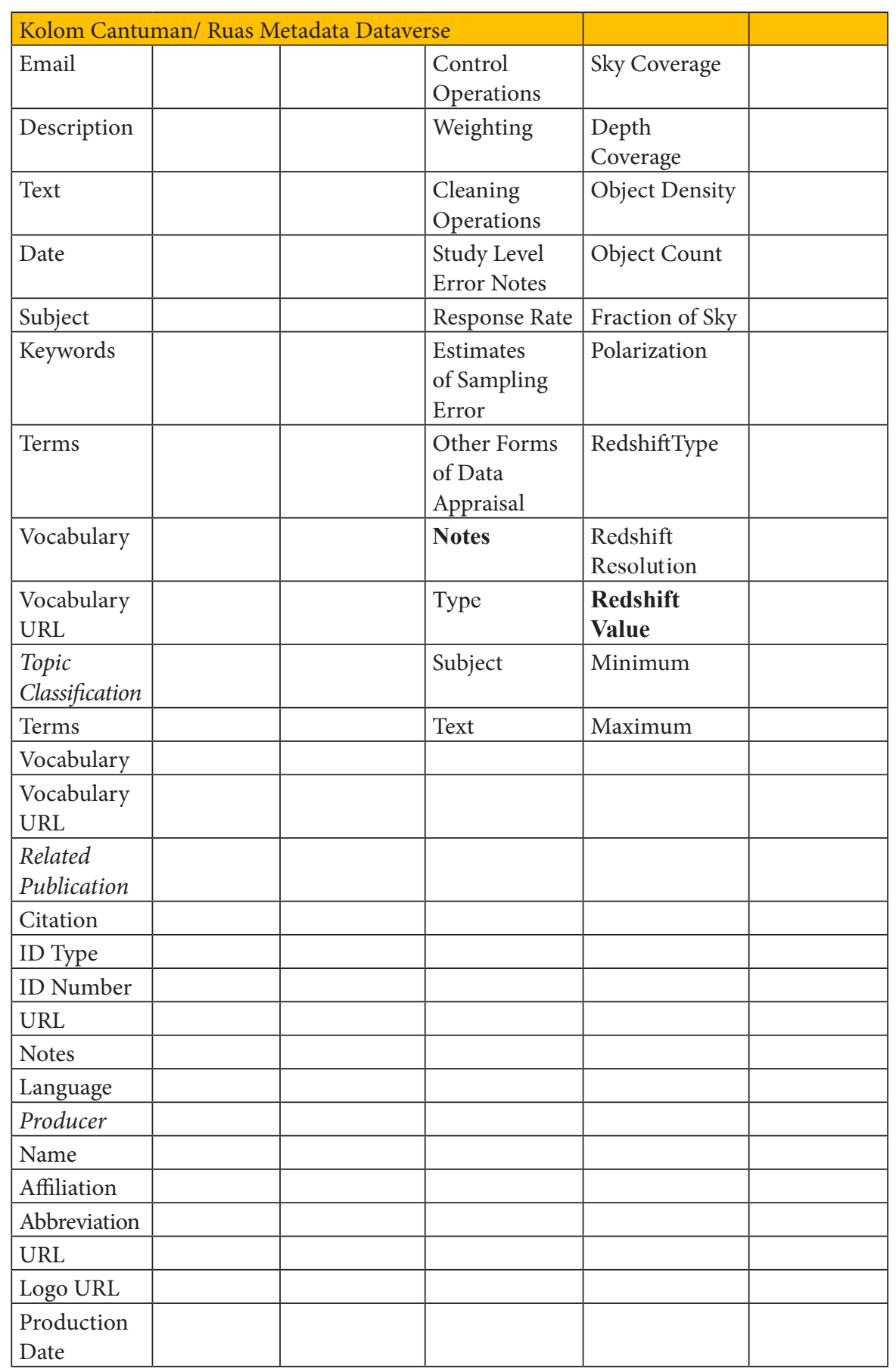


Manajemen Data Penelitian dengan Dataverse

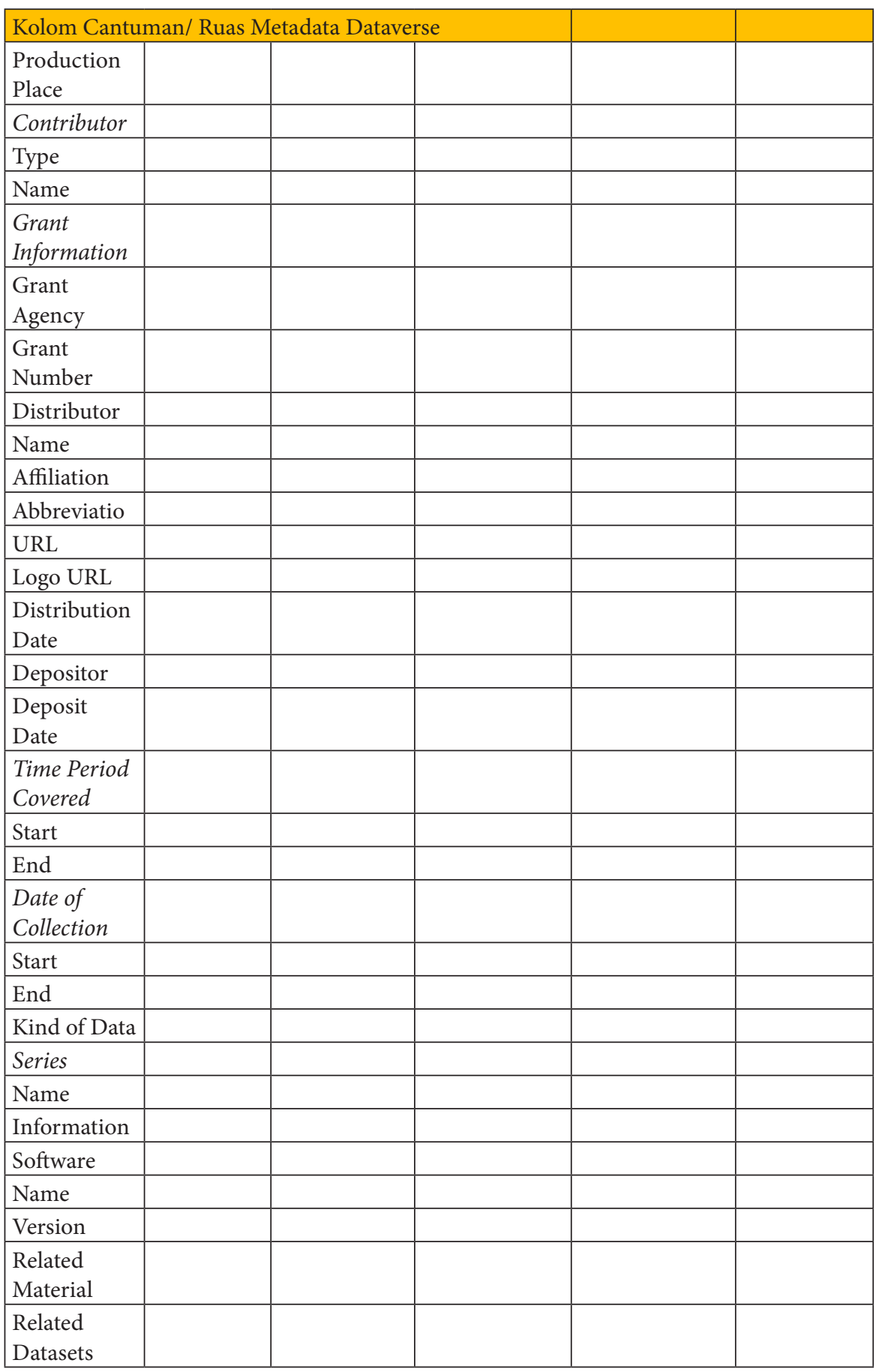




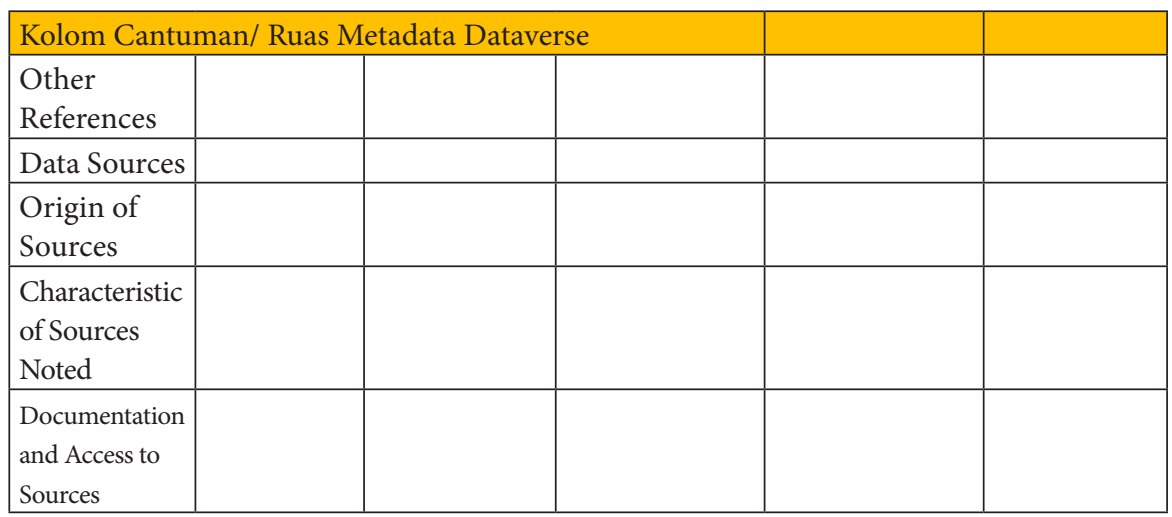

Sumber: Texas Data Repository Metadata Dictionary (Mumma, 2018)

\section{Mampu menggunakan thesaurus online dan mendeskripsikan kata kunci data}

Kata kunci pada Dataverse berguna untuk mempercepat pencarian informasi data dan pengindeksan di Daverse RIN. Agar dapat diindeks global, sebaiknya menggunakan kata kunci (keyword) berbahasa inggris dan terkendali. Berikut ini daftar dokumen thesaurus online untuk menentukan kata kunci data (Tabel 5).

Tabel 5. Daftar Thesaurus Online untuk Penentuan Kata Kunci

\begin{tabular}{|c|c|c|c|}
\hline No. & $\begin{array}{c}\text { Nama } \\
\text { Thesaurus }\end{array}$ & $\begin{array}{c}\text { Ruang Lingkup } \\
\text { Keilmuan }\end{array}$ & URL Website \\
\hline 1 & ASFA Thesaurus & $\begin{array}{l}\text { Ilmu Perairan, Kelautan, } \\
\text { \& Perikanan }\end{array}$ & $\begin{array}{l}\text { http://www.fao.org/3/a- } \\
\text { k5032e.pdf }\end{array}$ \\
\hline 2 & $\begin{array}{l}\text { UNESCO } \\
\text { Thesaurus }\end{array}$ & $\begin{array}{l}\text { Pendidikan, Budaya, } \\
\text { Ilmu Alam, Ilmu } \\
\text { Sosial \& Humaniora, } \\
\text { Komunikasi \& } \\
\text { Informasi }\end{array}$ & $\begin{array}{l}\text { http://vocabularies.unesco. } \\
\text { org/browser/thesaurus/en/ }\end{array}$ \\
\hline 3 & $\begin{array}{l}\text { AGROVOC } \\
\text { Multilingual } \\
\text { Thesaurus }\end{array}$ & Pertanian & $\begin{array}{l}\text { http://agrovoc.uniroma2. } \\
\text { it/agrovoc/agrovoc/ } \\
\text { en/?clang=es }\end{array}$ \\
\hline 4 & $\begin{array}{l}\text { OECD } \\
\text { Macrothesaurus } \\
\text { Chapter } \\
\text { Headings }\end{array}$ & Ekonomi & $\begin{array}{l}\text { http://bibliotecavirtual. } \\
\text { clacso.org.ar/ar/oecd- } \\
\text { macroth/en/index.htm }\end{array}$ \\
\hline
\end{tabular}


Manajemen Data Penelitian dengan Dataverse

\begin{tabular}{|c|l|l|l|}
\hline 5 & $\begin{array}{l}\text { The Merck } \\
\text { Index Online }\end{array}$ & Kimia, Farmasi, Biologi & $\begin{array}{l}\text { https://www.rsc.org/Merck- } \\
\text { Index/browse?atozfilter=A\& } \\
\text { pagenumber=1\&pagesize=20 }\end{array}$ \\
\hline 6 & $\begin{array}{l}\text { Medical Subject } \\
\text { Headings }\end{array}$ & $\begin{array}{l}\text { Kesehatan \& } \\
\text { Kedokteran }\end{array}$ & $\begin{array}{l}\text { https://meshb.nlm.nih.gov/ } \\
\text { search }\end{array}$ \\
\hline 7 & $\begin{array}{l}\text { USAID } \\
\text { Thesaurus }\end{array}$ & Sosial \& Ekonomi & $\begin{array}{l}\text { https://www. } \\
\text { vocabularyserver.com/usaid/ } \\
\text { index.php }\end{array}$ \\
\hline 8 & ILO Thesaurus \\
\hline 9 & $\begin{array}{l}\text { Ekonomi \& } \\
\text { Ketenagakerjaan } \\
\text { Subject } \\
\text { Headings }\end{array}$ & Seluruh Bidang & http://ilo.multites.net/ \\
\hline
\end{tabular}

\section{Mampu sebagai kolaborator penelitian}

Kolaborasi merupakan aktivitas berbagi ketrampilan, pengetahuan, dan pengalaman seseorang kepada orang lain yang bertujuan untuk membangun komunikasi dan kerjasama. Melalui kolaborasi, pustakawan dapat meningkatkan pondasi keilmiahan ilmu perpustakaan dan informasi, melahirkan pengetahuan baru, dan memberikan kontribusi pada pengembangan profesi pustakawan di masa mendatang (Borrego, Ardanuy, \& Urbano (2018). Dalam kolaborasi di kegiatan penelitian, ada beberapa tahapan yang perlu dilakukan oleh pustakawan, diantaranya: (1) penemuan gagasan-pencarian literatur, penulisan tinjauan pustaka, mengembangkan koleksi, memberikan pelatihan penelitian, meningkatkan literasi informasi; (2) pendanaan/ persetujuan-mendukung informasi pengajuan hibah dan pendanaan; (3) eksperimentasi-kurasi data, manajemen data, metadata; dan (4) diseminasi-repositori kelembagaan, akses terbuka, bibliometrik, penilaian penelitian, dukungan untuk publikasi. 


\section{Mampu menyediakan layanan data penelitian di perpustakaan}

Tenopir, Sandusky, Allard, \& Birch (2014) mengatakan bahwa praktik layanan data penelitian telah dilakukan oleh pustakawan di perpustakaan riset akademik di Amerika Serikat dan Kanada. Kebijakan layanan data penelitian di perpustakaan hanya sampai tahap perencanaan dan pendukung kegiatan penelitian bukan pekerjaan utama perpustakaan. Di perguruan tinggi, kegiatan ini banyak melibatkan pustakawan, mahasiswa dan direktur perpustakaan, bahkan staf fakultas untuk membantu layanan data penelitian. Pustakawan yang memberikan pelayanan ini setidaknya memiliki kompetensi sebagai subject spesialist dan dituntut aktif mensosialisasikan layanan data penelitian dalam berbagai kegiatan lokakarya dan konferensi. Beberapa bentuk layanan data penelitian, yaitu: (a) memberikan dukungan teknis untuk sistem layanan data penelitian, seperti repositori, akses, dan sistem penemuan; (b) Mengatur data agar tidak dapat diakses setalah terbit (deaccessioning) atau deseleksi data atau Dataset untuk dihapus dari tempat penyimanan; (c) mempersiapkan data atau kumpulan data untuk disimpan ke dalam repositori; (d) mmembuat atau mengubah metadata untuk data atau Dataset; (e) mengidentifikasi data atau Dataset yang dapat dimasukkan ke sistem repositori lembaga; (f) berpartisipasi langsung dengan para peneliti dalam suatu proyek penelitian.

\section{Mampu menggerakkan budaya literasi ilmiah atau research literacy}

Kompetensi literasi ilmiah terkait erat dengan kompetensi riset. Literasi ilmiah merupakan kompetensi utama, yang mewakili kemampuan untuk menggunakan pengetahuan dan informasi secara interaktif, dapat mengubah seseorang untuk berinteraksi dengan orang lain dan untuk mencapai tujuan yang lebih luas. Osborne (2002) 
mengatakan bahwa "science without literacy: a ship without a sail?" yang bermakna bahwa pengetahuan tanpa literasi ibarat kapal tanpa layar yang tidak jelas arahnya (tujuan); dan kunci dari pengetahuan yaitu komunikasi dengan bahasa ilmiah (biasa digunakan oleh para ilmuan). Kompetensi pustakawan dalam berliterasi ilmiah ini dapat dilakukan dengan cara: (1) menjelaskan fenomena secara ilmiah; (2) mengevaluasi dan merancang pertanyaan ilmiah; (3) menginterpretasikan data dan bukti secara handal (PISA, 2013). Komptensi literasi ilmiah juga dapat diwujudkan pustakawan dalam menjelaskan konsep ilmiah, proses ilmiah; dan situasi ilmiah berdasarkan bukti ilmiah (OECD, 2014).

\section{Simpulan}

Dataverse merupakan plaform pengelola data penelitian berbasis open source yang dapat digunakan untuk menyimpan, mempublikasikan, dan berbagi data dengan peneliti dan masyarakat global. Ketersediaan dan aksesibilitas data penelitian melalui Dataverse membuat data lebih bermakna karena data di sitasi dan memberikan impact factor bagi pengembangan iptek dan peningkatan kualitas penelitian berikutnya. Pemanfaatan Dataverse untuk layanan RIN memberikan kemudahan bagi para lembaga/ institusi, peneliti dan masyarakat untuk mengelola datanya secara mandiri dan terintegrasi, serta dapat disimpan dan diakses dalam jangka waktu yang panjang. Dalam mengelola Dataverse RIN, depositor data perlu memahami ketentuan dan tahapan pengelolaan data penelitian agar dalam pemanfaatannya efektif dan berdampak pada peningkatan kualitas penelitian. Seorang depositor harus memahami Dataverse, Dataset, dan file data yang dikelola melalui Dataverser RIN. Selain itu, depositor harus memahami setiap peran pengguna agar Dataverse, Dataset, dan file yang dipublikasikan dapat digunakan oleh pengguna berdasarkan batasan aksesnya, apakah untuk publik, grup/komunitas, atau tertutup. Terkait dengan pengelolaan dan pemanfaatan Dataverse RIN, pustakawan 
PDDI LIPI memiliki peran dan tantangan yang semakin besar untuk menyadarkan para peneliti dan sivitas akademika di berbagai universitas untuk berbagi data dan senantiasa meningkatkan kualitas penelitiannya. Peran pustakawan sebagai pengelola data penelitian harus aktif dalam penyusunan regulasi dan kebijakan pengelolaan data penelitian, memahami konsep dan proses validasi/kurasi data penelitian melalui Dataverse, kolaborasi penelitian, menyediakan layanan data penelitian di perpustakaan, dan membudayakan gerakan literasi ilmiah ke masyarakat. Berdasarkan pembahasan di atas, penulis berharap agar kajian ini dapat: (1) dimanfaatkan pustakawan untuk meningkatkan kompetensi pengelolaan data penelitian untuk kemajuan bidang kepustakawanan; dan (2) menjadi bahan masukan kebijakan pengelolaan data penelitian yang melibatkan peran aktif pustakawan khususnya di lembaga litbang dan perguruan tinggi di Indonesia. 


\section{DAFTAR PUSTAKA}

Borrego, Á., Ardanuy, J., \& Urbano, C. Librarians as Research Partners: Their Contribution to the Scholarly Endeavour Beyond Library and Information Science. The Journal of Academic Librarianship, July, 2018. 0-1. https://doi. org/10.1016/j.acalib.2018.07.012.

Carlson, Jake \& Ruth Kneale. Embedded librarianship in the research context: Navigating new waters. College \& Research Libraries News, 72(3), 2011, 167-170. https://doi. org/10.5860/crln.72.3.8530.

Dataverse. Dataverse User Guide, 2019. http:/guides.dataverse.org/ en/4.10.1/user/index.html (akses 28 Mei 2019).

DMPTool. Data Management General Guidance, 2019. https:// dmptool.org/general_guidance (akses 28 Mei 2019).

Farida, Umi. Pengelolaan Big Data pada Perpustakaan: Tantangan bagi Pustakawan di Era Perpustakaan Digital. Journal Net. Library and Information, Vol.1, No.1, Juni, 2018,19-29.

Kusumaningrum, Dwiatri, Slamet Riyanto, \& Hermin Triasih. Penerapan Data Curation Pada Perpustakaan Penelitian Dalam Mengelola Data Penelitian. Laporan Hibah Penelitian Bidang Kepustakawanan Tahun 2018. Jakarta: Perpustakaan Nasional RI, 2018.

MacMillan, Don. Data Sharing and Discovery: What Librarians Need to Know. The Journal of Academic Librarianship, 40, 2014, 541-549. http://dx.doi.org/10.1016/j.acalib.2014.06.011.

Mamtora, Jayshree. Transforming Library Research Services: Towards a Collaborative Partnership. Library Management, 34(4/5), 2013, 352-71.

McEniry, Matthew \& Courtney C. Mumma. Roles in the Texas Data Repository, 2018. https://texasdigitallibrary.atlassian. net/wiki/spaces/TDRUD/pages/495255555/Roles+in+the+ Texas+Data+Repository (akses 28 Mei 2019). 
Mumma, Courtney C. Texas Data Repository User Documentation/ Guides and Policies, 2018. https://texasdigitallibrary. atlassian.net/wiki/spaces/TDRUD/pages/493551668/ Metadata+Dictionary (akses 28 Mei 2019).

OECD. PISA Scientific Literacy: A Short Guide for Key Stage 4 Teachers. Teacher Support Materials. Crown copyright, 2014.

Osborne, Jonathan. Science Without Literacy: A Ship without A Sail?. Cambridge Journal of Education. 32(2), 2002, 203- 218 .

PISA. PISA 2015: Draft Science Framework, March 2013. http:// www.oecd.org/pisa/pisaproducts/Draft\%20PISA\%20 2015\%20Science\%20Framework\%20.pdf (accessed 5 February 2018).

Rychen, D. S., \& Salganik, L. H. (Eds.). Definition and Selection of Key competencies: Executive Summary. Göttingen, Germany: Hogrefe, 2003.

Tammaro, Anna Maria, Matusiak, Krystyna K., Sposito, Frank Andreas, Pervan, Anna, Casarosa, Vittore. Understanding roles and responsibilities of data curators: an international perspective. Libellarium: Journal for the Research of Writing, Books, and Cultural Heritage Institutions, 9(2), 2017, 39-48. http://doi.org/10.15291/libellarium.v9i2.286

Tempo.Co. Begini Strategi LIPI Digitalisasi Aset Perpustakaan, 2019. https://www.msn.com/id-id/berita/teknologidansains/ begini-strategi-lipi-digitalisasi-aset-perpusatakaan/arBBUWa0R (akses 27 Mei 2019).

Tenopir, Carol Robert J. Sandusky, Suzie Allard, \& Ben Birch. Research Data Management Services in Academic Research Libraries and Perceptions Of Librarians. Library \& Information Science Research, 36, 2014, 84-90. http:// dx.doi.org/10.1016/j.lisr.2013.11.003. 
Wittenberg, Jamie, Anna Sackmann, Rick Jaffe. Situating Expertise in Practice: Domain-Based Data Management Training for Liaison Librarians. The Journal of Academic Librarianship, 2018, https://doi.org/10.1016/j.acalib.2018.04.004.

Yoganingrum, Ambar, Ekawati Marlina, Hendro Subagyo, \& Diana Permata Sari Pembangunan Repositori Data Institusi Dan Pertukaran Data Antar Institusi Di Indonesia, 2015. 
